\title{
Avoidance of used endometrial sites by blastocysts of the bank vole, Clethrionomys glareolus
}

\author{
J. O. Nerquaye-Tetteh* and J. R. Clarke \\ Department of Zoology, University of Oxford, South Parks Road, Oxford OX1 3PS, UK
}

\begin{abstract}
Summary. In bank voles blastocysts arising from mating immediately after parturition do not implant in used zones of the preceding pregnancy but in the regions between them. However, if mating is postponed until 12 or more days after parturition blastocysts do implant in used zones of the previous pregnancy. Implantations also occur at zones used two pregnancies previously. It seems likely that the absence of implantations at recently used zones of the uterus is determined by the uterus rather than blastocysts.
\end{abstract}

Keywords: used endometrial sites; blastocysts; post-partum mating; bank vole

\section{Introduction}

In rodents the whole of the antimesometrial surface of the uterine luminal epithelium is potentially available for the implantation of blastocysts. This is in contrast to some other mammals in which implantation is restricted to particular uterine sites (Wimsatt, 1975). Implantation in primigravid bank voles occurs from 4 days $9 \mathrm{~h}$ to 4 days $12 \mathrm{~h}$ after mating (Andersson \& Gustafsson, 1979). They have a post-partum oestrus (Clarke \& Hellwing, 1983), and if suckling 3 or more young there is a delay of about 1.5 days in the implantation of blastocysts (Andersson \& Gustafsson, 1979). In the intensive production of bank voles in a laboratory colony (Baker \& Clarke, 1987) the modal value for intervals between births is 21 days (Clarke \& Hellwing, 1983). Such an uninterrupted sequence of pregnancies also occurs in laboratory colonies of a number of other rodent species (Poole, 1987), and also in wild populations of bank voles, field voles and wild rats (Brambell \& Rowlands, 1936; Brambell \& Hall, 1939; Davis \& Emlen, 1948). This raises the question of whether the implantation of blastocysts in parous rodents can occur anywhere along the length of the antimesometrial endometrium, or whether it is confined to regions between sites of implantation and placental development of the preceding pregnancy. Droogleever Fortuyn (1929), De Lange (1934) and Orsini (1962), on the basis of incidental observations in hamsters and the gundi, had made such a suggestion. Here we have tested the proposition that in bank voles blastocysts do not implant in the regions of the uterus used in the immediately preceding pregnancy, and have attempted to characterize the difference, from the point of view of implantation, between used and unused zones.

\section{Materials and Methods}

In several rodents the regions of the uterus which have been occupied by fetuses are identifiable by so-called placental scars occurring on the mesometrial side of the uterus (Droogleever Fortuyn, 1929; Deno, 1937; Davis \& Emlen, 1948; Momberg \& Conaway, 1956; Orsini, 1962; Alibhai, 1982). In a primiparous bank vole at 5-7 days post partum placental scars, henceforth to be called nodules (Deno, 1937; Brandon, 1990), are readily seen as yellow or pale brown ovoid structures, $1.5 \times 1.0 \mathrm{~mm}$ and weighing no more than $2 \mathrm{mg}$, projecting slightly from the mesometrial aspect of

\footnotetext{
*Present address: Department of Biological Sciences, University of Science \& Technology, Kumasi, Ghana.
} 
the uterine horns (J. R. Clarke, unpublished observations). Older nodules are smaller and paler than the more recent ones. Nodules serve as markers of regions of the uterus which have been occupied by fetuses. These regions will be called 'used zones' in contrast to 'unused zones'.

Animals for these experiments were from the breeding colony now in the Department of Zoology, Oxford University. The husbandry of these bank voles has been described by Baker \& Clarke (1987). Experimental females were virgin, sexually mature, and 3-6 months old. Ovariectomy, and injection of pontamine sky blue $(0.3 \mathrm{ml}$ of a $0.1 \%$ solution in physiological saline) into the external jugular vein, was carried out under Saffan (alphaxalone:alphadolane acetate: Glaxovet Ltd, Uxbridge, UK) anaesthesia (approximately $0.1 \mathrm{ml} / 10 \mathrm{~g}$ body weight). Intact and unilaterally ovariectomized females were paired permanently with fertile males. In the case of the unilaterally ovariectomized females, pairing was 3 days after the operation. Pregnancy was diagnosed by increase in body weight (Baker \& Clarke, 1987). Cages were inspected twice daily on the days of expected parturition, and young were removed as soon as they were found.

Experiment 1 . The comparatively small size of the first litter for this bank vole breeding colony $(3 \cdot 2 \pm 0 \cdot 1$, Clarke, 1985) would suggest the existence of ample unused regions for the implantation of subsequent blastocysts. To test the question more stringently, unilaterally ovariectomized as well as intact bank voles were studied. Since there is little likelihood of migration of oocytes or preimplantation embryos from one uterine horn to the other (Brambell \& Rowlands, 1936), unilateral ovariectomy should lead to greater crowding of the contralateral uterine horn (Biggers et al., 1962; Norris \& Adams, 1982).

Females mated in the $24 \mathrm{~h}$ after parturition, as indicated by vaginal plugs or by spermatozoa in vaginal smears. The day of mating was designated as Day 1 of the second pregnancy. On Day 6, when implantation would have been expected to have taken place (Anderssen \& Gustafsson, 1979), females were injected with pontamine sky blue (PSB) to reveal the implantation sites (Psychoyos, 1961). Animals were killed 15 min after starting the PSB injection. Uteri were examined in situ, and the relationship of nodules to blue implantation sites was recorded by sketches. Uteri were dissected out, horns stretched slightly to their natural length, pinned to card and fixed in formol-glacial acetic acid$95 \%$ ethanol $(1: 1: 3$, by vol.) diluted $1: 1$ with distilled water. This allowed a second assessment later of the relationship of implantation sites to nodules.

Experiment 2. Ten intact and 6 unilaterally ovariectomized females were mated between Day 1 and Day 30 following the birth of their first litters. On Day 6 after mating they were injected intravenously with PSB, killed 15 min later and the relationship of implantation sites to nodules recorded as described above.

Experiment 3. Stud males were removed from the cages of intact (Group 1) and unilaterally ovariectomized (Groups $2 \mathrm{a} \& \mathrm{~b}$ ) females when they were clearly pregnant. Both ovaries in Group I, and the remaining ovary in Groups $2 \mathrm{a}$ and $\mathrm{b}$, were removed following parturition. At 2 days after ovariectomy all females were treated over 11 days with oestrogen and progesterone according to the schedule which allows a reliable decidual cell reaction to be evoked in bank voles following traumatization on Day 9 of the hormone treatment (Nerquaye-Tetteh \& Clarke, 1987). Uteri of animals in Groups 1 and 2a were traumatized as follows. On one horn of Group 1 females transverse crushes were made with fine ('mosquito') artery forceps on the used zones. On the contralateral horn the same number of crushes was made on unused zones. With females of Group 2a transverse crushes were made at used zones of the fertile horn. The same number of crushes was given on the contralateral sterile horn, spaced in phase with the used zones of the fertile horn. The uterine horns of animals in Group $2 b$ were not traumatized. Females were killed 3 days after traumatization of the uterus, or, in the case of Group 2b, at the corresponding time post partum. Whole uterine horns of all groups were weighed first, and then individual decidual swellings, whether at used or unused zones, were cut out and weighed. Significance of differences between means was assessed by the paired $t$ test (Bailey, 1981).

\section{Results}

\section{Experiment 1: do blastocysts arising from a post-partum fertilization implant in recently used zones?}

In no instance, involving a total of 15 intact and 9 unilaterally ovariectomized females, with a total of 94 used zones of the first pregnancy and 121 new implantations of the next, was there any overlap of the used zones and the sites of new implantations, identified by PSB (Table 1).

\section{Experiment 2: are used zones re-usable?}

The 10 intact and 6 unilaterally ovariectomized females had a total of 46 nodules from the first pregnancy and 66 implantations for the second. There were 4 instances of complete overlap of implantation sites with nodules. Mating had occurred at 12 days (one instance), 21 days ( 2 instances) and 30 days ( 1 instance) post partum, and the implantations were detected at 17,26 and 35 days post partum. An additional female had 2 pregnancies and mated immediately after the birth of the second litter. One implantation site of the third pregnancy overlapped completely a nodule 
Table 1. Total of nodules (= used zones) of one pregnancy and total implantations of the next pregnancy in bank voles

\begin{tabular}{|c|c|c|c|c|}
\hline & \multicolumn{2}{|c|}{ Intact females } & \multicolumn{2}{|c|}{$\begin{array}{c}\text { Unilaterally } \\
\text { ovariectomized females }\end{array}$} \\
\hline & $\begin{array}{l}\text { Nodules } \\
(\mathrm{N}=15)\end{array}$ & $\begin{array}{l}\text { Implantations } \\
(\mathrm{N}=15)\end{array}$ & $\begin{array}{l}\text { Nodules } \\
(N=9)\end{array}$ & $\begin{array}{l}\text { Implantations } \\
\qquad(\mathrm{N}=9)\end{array}$ \\
\hline & 2 & 6 & 2 & 4 \\
\hline & 3 & 2 & 3 & 6 \\
\hline & 3 & 4 & 3 & 7 \\
\hline & 3 & 5 & 4 & 3 \\
\hline & 3 & 5 & 4 & 5 \\
\hline & 3 & 6 & 4 & 5 \\
\hline & 4 & 4 & 4 & 6 \\
\hline & 4 & 4 & 4 & 7 \\
\hline & 4 & 5 & 5 & 4 \\
\hline & 4 & 5 & & \\
\hline & 4 & 7 & & \\
\hline & 5 & 5 & & \\
\hline & 5 & 6 & & \\
\hline & 6 & 6 & & \\
\hline & 8 & 4 & & \\
\hline Total & 61 & 74 & 33 & 47 \\
\hline Mean \pm s.e.m. & $4 \cdot 1 \pm 0.4$ & $4 \cdot 9 \pm 0 \cdot 3$ & $3.7 \pm 0.3$ & $5 \cdot 2 \pm 0 \cdot 5$ \\
\hline
\end{tabular}

Table 2. Weights $(\mathrm{mg})$ of uterine horns and decidual swellings in bank voles following treatment with oestrogen and progesterone, and crushing trauma of the uterus

\begin{tabular}{lcc}
\hline & $\begin{array}{c}\text { Intact } \\
\text { females } \\
(\mathrm{N}=5)\end{array}$ & $\begin{array}{c}\text { Unilaterally } \\
\text { ovariectomized } \\
\text { females } \\
(\mathrm{N}=5)\end{array}$ \\
\hline $\begin{array}{l}\text { Uterine horn: crushing on used zones } \\
\begin{array}{l}\text { Contralateral uterine horn: crushing } \\
\text { between used zones or at } \\
\text { corresponding sites in sterile horn }\end{array}\end{array}$ & $60 \cdot 9 \pm 17 \cdot 5^{\mathrm{a}}$ & $66 \cdot 7 \pm 17 \cdot 5^{\mathrm{a} \prime}$ \\
$\begin{array}{l}\text { Decidual swellings at used zones } \\
\text { Decidual swellings on contralateral } \\
\text { horn between used zones, or on } \\
\text { contralateral sterile horn }\end{array}$ & $24 \cdot 3 \pm 6 \cdot 9 \cdot 2^{\mathrm{b}}$ & $30 \cdot 4 \pm 6 \cdot 4^{\mathrm{a}}$ \\
\hline
\end{tabular}

Values are mean \pm s.e.m.

Differences a-a, $\mathrm{a}^{\prime}-\mathrm{a}^{\prime}, P=0.05-0.02 ; \mathrm{b}-\mathrm{b}, P=0.02-0.01 ; \mathrm{c}-\mathrm{c}, P=0.01-0.002$ (paired $t$ test).

from the first pregnancy, recognizable by its smaller size and paler colour. There was no overlap with nodules of the second pregnancy.

\section{Experiment 3: decidual cell reaction at used and unused uterine zones}

Traumatization evoked decidualization in all animals. In intact females (Table 2) uterine horns which had been traumatized at used zones weighed significantly more than contralateral horns in which the same number of unused zones had been traumatized. Individual decidual swellings at 
used zones were significantly heavier than the swellings at unused zones. Similarly, in females which at the outset had been unilaterally ovariectomized the fertile horns which had been traumatized at used zones were significantly heavier than the sterile horns traumatized at an equal number of corresponding places. In females of Group $2 b$, which had been treated in exactly the same way except for the omission of traumatization, fertile horns were heavier than sterile horns $(19.6 \pm 0.9 \mathrm{mg}, 9.6 \pm 0.4 \mathrm{mg}, P<0.001)$. Subtracting these mean values from the corresponding weights of fertile and sterile horns in Group 2a the difference in weight between horns traumatized at used zones and traumatized sterile horns is still statistically significant. In any case individual decidual swellings at used zones were significantly heavier than the corresponding traumatized zones of the contralateral sterile horn.

\section{Discussion}

The results of this study indicate that in bank voles the blastocysts arising from fertilization immediately post partum avoid the zones of the endometrium which had been occupied by embryos and fetuses in the preceding pregnancy. However, from about 17 days post partum used zones once more became available for implantation. Momberg \& Conaway (1956) had recognized in rats that nodules from a second pregnancy can overlap with those of a first, without reporting the interval between the first and second pregnancies.

In ovariectomized bank voles treated with oestrogen and progesterone, fertile uterine horns, whether traumatized or not, were heavier than contralateral sterile horns. To this extent our results agree with the findings of Brandon (1990) for the mouse. Parkes (1928), on the other hand, reported that 'placentomata' produced in the uterus of the lactating mouse were not as large as those in the pseudopregant animal. He did not specify where, in relation to nodules, threads used to evoke the decidual cell reaction had been inserted. In the bank vole the decidual cell reaction in response to crushing was larger at used than at unused zones. This is the opposite of what had been expected. Since blastocysts arising from a post-partum mating implanted exclusively at unused zones, it had been anticipated that the response to trauma would be greater at unused than at used zones of the uterus. Nodules present at used zones are unlikely to have contributed in any important way to the greater weight of decidual swellings at these regions, since at the stage post partum when the decidual swellings were weighed nodules are about $0.5 \mathrm{mg}$, although they are readily recognized macroscopically $(J$. R. Clarke, unpublished observations). Compensating for the weight of nodules does not alter the statistical significance of the results. In contrast, Brandon (1990) found that the decidual response at used zones in mice was more frequently less than at the adjacent unused zones. Brandon's (1990) results recall the finding that, in the $24 \mathrm{~h}$ after one decidualizing stimulus given to the pseudopregnant rat, there is a decrease in the sensitivity to a second (De Feo, 1963; Sanders et al., 1986).

The occurrence of ectopic pregnancies either naturally in women or experimentally in laboratory mice (Kirby, 1963, 1967) indicates that blastocysts will attach to cell surfaces or interact with tissues quite different from the endometrium. This suggests that the failure of implantations to occur at used zones may involve defects in, or adverse effects of, signals passing between blastocysts and the endometrium (Heap et al., 1981; Kennedy \& Armstrong, 1981).

Further investigation of the apparent difference between used and unused zones would be aided by an artificial, easily regulated, stimulus taking the place of blastocysts and acting upon the endometrium through the luminal epithelium. We have used crushing trauma because it evokes a well defined decidual cell reaction in a reliable fashion (Nerquaye-Tetteh \& Clarke, 1987), but it has an obvious defect since it is indiscriminate in what it stimulates. The intraluminal instillation of oil might at first sight seem a reasonable method (see Finn \& Porter, 1975). Brandon (1990) instilled arachis oil into post-partum uteri of mice. This evoked well defined, regularly spaced, decidual swellings at used and unused parts of the uteri. However, we have found in limited tests with the field vole, as did Milligan (1974), that the decidual response to intraluminal arachis oil is appreciably more variable than the response to trauma. 
Histochemical (Finn \& Hinchcliffe, 1964, 1965), electron microscopic (Pollard \& Finn, 1972), biochemical (Sanders et al., 1986), or in-vitro methods (Grant et al., 1975; Sherman, 1978; Glasser \& McCormack, 1981) might define differences between the endometrium of used and unused zones that are significant for implantation. It may also be important to know more about the origin of nodules (Selye \& McKeown, 1935; Deno, 1937; Masson \& Selye, 1942; Baker, 1948; Gitlin \& Weiner, 1959; Stewart, 1988). However, there may be a quite different explanation for the avoidance by blastocysts of recently used zones. It has been suggested that the spacing of implantations in mice or rabbits may be brought about by movements of the uterus (Hollander \& Strong, 1950; Böving, 1954; McLaren \& Michie, 1959). More recent experimental studies with rats have provided further evidence of the importance of myometrial activity in determining the spacing of blastocysts (Rogers et al., 1983; Legrand et al., 1987, 1989). In bank voles the mesometrial aspect of the uterine luminal epithelium is repaired by Day 5 post partum, but the continuity of the cylinder of circular smooth muscle comprising part of the myometrium is interrupted by nodules for the first 15-20 days post partum (J. R. Clarke, unpublished observation). Disruption of myometrial smooth muscle by metrial gland cells has also been recognised in pregnant mice and rats (Bloch, 1964; Bulmer et al., 1983). When fertilization has occurred in the first 8 or 9 days post partum it seems possible that changed organization of the smooth muscle affects the spacing of blastocysts in the uterus.

We thank Janet Evans and Valerie Petts for invaluable assistance with this work. J.O.N.-T was supported by a Ghana State Studentship.

\section{References}

Alibhai, S.K. (1982) Persistence of placental scars in the bank vole, Clethrionomys glareolus. J. Zool., Lond. $197,300-302$.

Andersson, C.B. \& Gustafsson, T.O. (1979) Delayed implantation in lactating bank voles, Clethrionomys glareolus. J. Reprod. Fert. 57, 349-352.

Bailey, N.J.T. (1981) Statistical Methods in Biology. Hodder \& Stoughton, London.

Baker, B.L. (1948) Histochemical variations in the metrial gland of the rat during pregnancy and lactation. Proc. Soc. exp. Biol. Med. 68, 492-496.

Baker, J.P. \& Clarke, J.R. (1987) Voles. In The UFAW Handbook on the Care and Management of Laboratory Animals, 6th edn, pp. 331-345, Ed. T. B. Poole. Longman Scientific \& Technical, London.

Biggers, J.D., Finn, C.A. \& McLaren, A. (1962) Long term reproductive performance of female mice. II. Variation of litter-size with parity. J. Reprod. Fert. 3, 313-330.

Bloch, S. (1964) Die glandula myometralis im Uterus der Maus. Acta anat. 56, 103-119.

Böving, B.G. (1954) Blastocyst/uterine relationships. Cold Spring Harb. Symp. quant. Biol. 19, 9-28.

Brambell, F.W.R. \& Hall, K. (1939) Reproduction of the field voles, Microtus agrestis hirtus Bellamy. Proc. zool. Soc. Lond. 109 A, 133-138.

Brambell, F.W.R. \& Rowlands, I.W. (1936) Reproduction in the bank vole, Evotomys glareolus, Schreber. Phil. Trans. R. Soc. 226, $71-97$.

Brandon, J.M. (1990) Decidualization in the post-partum uterus of the mouse. J. Reprod. Fert. 88, 151-158.

Bulmer, D., Stewart, I. \& Peel, S. (1983) Endometrial granulocytes of the pregnant hamster. J. Anat. 136, 329-337.

Clarke, J.R. (1985) The reproductive biology of the bank vole (Clethrionomys glareolus) and the wood mouse
(Apodemus sylvaticus). Symp. zool. Soc. Lond. 55, $33-59$.

Clarke, J.R. \& Hellwing, S. (1983) Fertility of the postpartum bank vole (Clethrionomys glareolus). $J$. Reprod. Fert. 68, 241-246.

Davis, D.E. \& Emlen, J.T. (1948) The placental scar as a measure of fertility in rats. J. Wildl. Mgmt 12, 162-166.

De Feo, J.V. (1963) Determination of the sensitive period for the induction of deciduomata in the rat by different inducing procedures. Endocrinology 73, 488-497.

De Lange, D. (1934) Beobachtungen an puerperalen und schwangeren Uteri von Ctenodactylus gundi. $Z$. mikrosk.-anat. Forsch. 36, 488-496.

Deno, R.A. (1937) Uterine macrophages in the mouse and their relation to involution. Am. J. Anat. 60, $433-471$.

Droogleever Fortuyn, A.B. (1929) Prenatal death in the striped hamster (Cricetulus griseus, M.-Edw.). Archs Biol. 39, 583-606.

Finn, C.A. \& Hinchcliffe, J.R. (1964) Reaction of the mouse uterus during implantation and deciduoma formation as demonstrated by changes in the distribution of alkaline phosphatase. J. Reprod. Fert. 8, 33 !-338.

Finn, C.A. \& Hinchcliffe, J.R. (1965) Histological and histochemical analysis of the formation of implantation chambers in the mouse uterus. J. Reprod. Fert. 9, 301-309.

Finn, C.A. \& Porter, D.G. (1975) The Uterus. Elek Science, London.

Gitlin, G. \& Weiner, A. (1959) The postnatal degeneration of the metrial (myometrial) glands in the white rat. Endocrinology 65, 973-976.

Glasser, S.R. \& McCormack, S.A. (1981) Separated cell types as analytical tools in the study of decidualization and implantation. In Cellular and Molecular Downloaded from Bioscientifica.com at 04/25/2023 11:51:49PM 
Aspects of Implantation, pp. 217-239. Eds S. R. Glasser \& D. W. Bullock. Plenum Press, New York.

Grant, P.S., Ljungkvist, I. \& Nilsson, O. (1975) The hormonal control and morphology of blastocyst invasion in the mouse uterus in vitro. J. Embryol. exp. Morph. 34, 299-310.

Heap, R.B., Flint, A.P.F. \& Gadsby, J.E. (1981) Embryonic signals and maternal recognition. In Cellular and Molecular Aspects of Implantation, pp. 311-326. Eds S. R. Glasser \& D. W. Bullock. Plenum Press, New York.

Hollander, W.F. \& Strong, L.C. (1950) Intrauterine mortality and placental fusion in the mouse. $J$. exp. Zool. 115, 131-147.

Kennedy, T.G. \& Armstrong, D.T. (1981) The role of prostaglandins in endometrial vascular changes at implantation. In Cellular and Molecular Aspects of Implantation, pp. 349-363. Eds S. R. Glasser \& D. W. Bullock. Plenum Press, New York.

Kirby, D.R.S. (1963) Some aspects of extrauterine pregnancies in rodents. D. Phil. thesis, Oxford University.

Kirby, D.R.S. (1967) Ectopic autografts of blastocysts of mice maintained in delayed implantation. $J$. Reprod. Fert. 14, 515-517.

Legrand, C., Banuelos-Nevarez, A., Rigolot, C. \& Maltier, J.P. (1987) Comparative effects of 6-hydroxydopamine and adrenoreceptor antagonists on intrauterine migration and spacing of blastocysts in the rat. $J$. Reprod. Fert. 81, 51-58.

Legrand, C., Banuelos-Nevarez, A. \& Maltier, J.P. (1989) Changes in electrical activity of myometrium during intrauterine distribution of rat blastocysts and after prazosin administration. J. Reprod. Fert. 86, 39-49.

Masson, G. \& Selye, H. (1942) Response of metrial gland to treatment with various steroids. Endocrinology 31, $549-552$.

McLaren, A. \& Michie, D. (1959) The spacing of implantations in the mouse uterus. In Implantation of $O \mathrm{va}$ (Mem. Soc. Endocr. No. 6), pp.65-75. Ed. P. Eckstein. Cambridge University Press.

Milligan, S.R. (1974) Some aspects of reproduction in the female vole, Microtus agrestis. D. Phil. thesis, Oxford University.

Momberg, H. \& Conaway, C. (1956) The distribution of placental scars of first and second pregnancies in the rat. J. Embryol. exp. Morph. 4, 376-384.

Nerquaye-Tetteh, J.O. \& Clarke, J.R. (1987) Hormonal requirements and the influence of age on the decidual cell reaction in the bank vole(Clethrionomys glareolus). J. Reprod. Fert. 79, 575-579.

Norris, M.L. \& Adams, C.E. (1982) Lifetime reproductive performance of Mongolian gerbils (Meriones unguiculatus) with 1 or 2 ovaries. Lab. Anim. 16, $146-150$.

Orsini, M.W. (I962) Technique of preparation, study and photography of benzyl-benzoate cleared material for embryological studies. $J$. Reprod. Fert. 3, 283-287.

Parkes, A.S. (1928) The functions of the corpus luteum. II The experimental production of placentomata in the mouse. Proc. R. Soc. B 104, 183-188.

Pollard, R.M. \& Finn, C.A. (1972) Ultrastructure of the uterine epithelium during hormonal induction of sensitivity and insensitivity to decidual stimuli in the mouse. J. Endocr. 55, 293-298.

Poole, T.B. (1987) The UFAW Handbook on the Care and Management of Laboratory Animals, 6th edn. Longman Scientific \& Technical, London.

Psychoyos, A. (1961) Nouvelle contribution à l'étude de la nidation de l'oeuf chez la ratte. C. r. hebd. Séanc. Acad. Sci. Paris D 251, 3073-3075.

Rogers, P.A.W., Murphy, C.R., Squires, K.R. \& MacLennan, A.H. (1983) Effects of relaxin on the uterine distribution and antimesometrial positioning and orientation of rat blastocysts before implantation. J. Reprod. Fert. 68, 431-435.

Sanders, R.B., Bekairi, A.M., Abulaban, F.S. \& Yochim, J.M. (1986) Uterine adenylate cyclase in the rat: responses to a decidual-inducing stimulus. Biol. Reprod. 35, 100-105.

Selye, H. \& McKeown, T. (1935) Studies on the physiology of the maternal placenta in the rat. Proc. $R$. Soc. $B$ 119, 1-31.

Sherman, M.l. (1978) Implantation of mouse blastocysts in vitro. In Methods in Mammalian Reproduction, pp. 247-257. Ed. J. C. Daniel. Academic Press, New York.

Stewart, I. (1988) Granulated metrial gland cells in the non-traumatized regions of the uterus of ovariectomized mice with deciduomata maintained on progesterone. J. Endocr. 116, 11-15.

Wimsatt, W.A. (1975) Some comparative aspects of implantation. Biol. Reprod. 12, 1-40.

Received 29 December 1989 